DOI 10.15290/cnisk.2019.01.06.08

DR HAB. PROF. NZW. ROBERT SUSKI

https://orcid.org/0000-0001-5227-2743

Uniwersytet w Białymstoku

\title{
Senaculum, czyli senat kobiet w Historia Augusta - dyskurs antychrześcijański czy mizoginizm?
}

\section{Streszczenie}

W Historia Augusta, zbiorze biografii cesarskich, w których autor przyjał sześć fikcyjnych pseudonimów oraz ukrył czas napisania swojego dzieła, dwukrotnie pojawia się termin senaculum, senat kobiet. Dzieło to jest pełne nieprawdziwych faktów, więc instytucja została najprawdopodobniej wymyślona przez autora. Najczęściej widzi się w niej żart $z$ listów Hieronima lub Nowego Testamentu. Uważam, że należy interpretować te wzmianki przez pryzmat antykobiecych uprzedzeń autora.

Słowa kluczowe: Historia Augusta, senaculum, mulierum senatum, Hieronim, kryzys III wieku

\section{SENACULUM, OR WOMEN'S SENATE IN THE HISTORIA AUGUSTA - ANTI-CHRISTIAN DISCOURSE OR MISOGYNY?}

\begin{abstract}
The Historia Augusta [Augustan History] is a specific collection of imperial biographies, which confirms the fact that its author wrote his work under six fictitious pseudonyms and lied about the time of its creation. It is not obvious when the Historia Augusta exactly was written, but surely after the time indicated by the author. Saneaculum (the Women's Senate) is mentioned in the Historia Augusta twice, but, as the work is full of false facts,
\end{abstract}


it is likely that the Women's Senate was made up by the author. Historians most often perceive this institution as a joke referring to the letters of Saint Jerome or the New Testament. In this article, it is shown that mentions about the Saneaculum should rather be interpreted as anti-feminist prejudice of the author of the Historia Augusta.

Keywords: Historia Augusta [Augustan History], Senaculum, Women's Senate, Jerome, crisis of 3rd century AD

\section{Wstęp}

W Historia Augusta dwa razy wspomniane jest zgromadzenie matron. Po raz pierwszy w biografii Heliogabala. Wedle jej autora na wzgórzu Kwirynał cesarz ustanowił drugi senat dla kobiet. W czasach Heliogabala senat ten zajmował się takimi kwestiami jak ubiór mężatek, sposób witania się, wykorzystywany przez nie transport czy używanie ozdób ${ }^{1}$ Mniej obszerny jest drugi passus dotyczacy zgromadzenia matron. Zdaniem autora Historia Augusta owa instytucję zamierzał przywrócić Aurelian, a na pierwszych miejscach miały zasiadać kapłanki ${ }^{2}$ To miała być jedna $z$ wielu reform podobno przygotowanych przez władcę, wzmacniajaca dyscyplinę w społeczeństwie (obok zakazu konkubinatu dla wolnych kobiet, noszenia purpurowych butów przez mężczyzn czy ograniczenia liczby posiadanych eunuchów). W tym tekście chciałbym się zastanowić nad rola, jaka w narracji autora Historia Augusta pełnia te dwie wzmianki.

\section{Rozwinięcie}

Dla większości badaczy fikcyjny charakter tych wzmianek nie budzi wątpliwości. Jedynie nieliczni wierza w istnienie senatu kobiet w cza-

\footnotetext{
1 Historia Augusta, Antoninus Heliogabalus, 4, 3-4: „fecit et in colle Quirinali senaculum, id est mulierum senatum, in quo ante fuerat conventus matronalis, solemnibus dumtaxat diebus et si umquam aliqua matrona consularis coniugii ornamentis esset donata, quod veteres imperatores adfinibus detulerunt et his maxime, quae nobilitatos maritos non habuerant, ne innobilitat $<a>e$ remanerent. $s<u b>$ Symiamira facta sunt senatus consulta ridicula de legibus matronalibus: quae quo vestitu incederet, quae cui cederet, quae ad cuius osculum veniret, quae pilento, quae $<$ e $>$ quo, qu<a $>$ e sagmario, quae asino veheretur, quae carpento mulari, quae bovum, quae sella veheretur et utrum pellicia $<a>n$ osse $<\mathrm{a}>$ an eborata an argentata, et quae aurum vel gemmas in calciamentis haberent". 2 Historia Augusta, Divus Aurelianus, 49, 6: „Senatum sive senaculum matronis reddi voluerat, ita ut primae illic quae sacerdotia senatu auctore meruissent”.
} 
sach cesarstwa ${ }^{3}$. Badacze, którzy chca w to wierzyć, zwracają uwagę na inskrypcję $z$ Lanuvium, która powstała w II lub III w., a wymienia curie mulierum epulum ${ }^{4}$, oraz na passus $z$ żywota Galby Swetoniusza, w którym opowiada się o kłótni między Agrypiną Młodszą a matką Domicji Lepidy podczas zebrania kobiet (conventu matronarum) ${ }^{5}$. Ponadto przypomina się o inskrypcji z Rzymu $z$ Forum Trajana, w której wspomina się o odnowieniu matronom (tyle że nie wiemy czego) przez Julię Augustę (zapewne Julię Domnę) ${ }^{6}$. Wreszcie w 1905 r. odkryto na Kwirynale posagi dwóch matron, co skojarzono $z$ ustępem z Historia Augusta ${ }^{7}$. W pierwszym przypadku $z$ Lanuvium mamy do czynienia $z$ kultem religijnym i stowarzyszeniem kultowym. W drugim zaś nie jest oczywiste, w jakich okolicznościach teściowa Galby zelżyła słowami (ale doszło też do rękoczynów) kobietę (Agrypinę Młodsza), która próbowała uwieść męża jej córki. Kontekst wydaje się raczej dosyć niewinny ${ }^{8}$. W odniesieniu do posagów $z$ Kwirynału powiazanie ich $z$ senatus mulierum jest bardzo arbitralne i nieuzasadnione ${ }^{9}$. Oczywiście jeszcze w czasach republikańskich istniały stowarzyszenia kultowe kobiet $^{10}$, co jednak nie jest równoznaczne z potwierdzeniem historyczności wzmianek z Historia Augusta. Do tego

\footnotetext{
3 Sarah B. Pomeroy, Goddesses, Whores, Wives and Slaves: Women in Classical Antiquity, (New York : Schocken Books, 1975), 246; Anna Pasqualini, „CIL XIV 2120, la curia mulierum di Lanuvio e l'«associazionismo" delle donne romane”, w: Alfredo Buonopane, Francesca Cenerini (ed.), Donna e vita cittadina nella documentazione epigrafica, (Faenza : Stabilimento Grafico Lega, 2005), 259-274; Emily A. Hemelrijk, Hidden Lives, Public Personae: Women and Civic Life in the Roman West (Oxford : Oxford University Press, 2015), 215-216. Często autorzy nie próbuja zajać jednoznacznego stanowiska, patrz: Eadem, Matrona docta, Educated women in the Roman élite from Cornelia to Julia Domna, (London-New York : Routledge, 1999), 12; Martijn Icks, The crimes of Elagabalus: the life and legacy of Rome's decadent boy emperor, (London : I.B. Tauris, 2011), 19; Leonardo de Arrizabalaga y Prado, Varian Studies Volume One: Varius (Cambridge : Cambridge Scholars Publishing, 2017), 327-328 .

4 CIL XIV 2120 = Dessau 6199. Patrz: Angela Donati, „Sull’iscrizione lanuvina della curia mulierum", Rivista di storia antica, vol. 1, 1971, 235-237.

5 Swetoniusz, Vita Galbae, 5, 1: „Dedit et matrimonio operam; verum, amissa uxore Lepida duobusque ex ea filiis, remansit in caelibatu, neque sollicitari ulla condicione amplius potuit, ne Agrippinae quidem, viduatae morte Domitii, quae maritum quoque adhuc necdum caelibem Galbam adeo omnibus sollicitaverat modis, ut conventu matronarum correpta iurgio atque etiam manu pulsata sit a matre Lepidae".

6 CIL VI 997 = ILS 324.

7 Patrz: Robert Turcan, Histoire Auguste, 3.1: Vies de Macrin, Diaduménien, Héliogabale, (Paris : Les Belles Lettres, 1993), 165.

8 David Rohrbacher, The Play of Allusion in the Historia Augusta, (Madison : University of Wisconsin Press, 2016), 116.

9 Robert Turcan, Histoire Auguste, 3.1, 165.

10 Ibidem.
} 
słowo senaculum poświadczone jest w kilku źródłach, ale jego znaczenie jest inne niż we wzmiankowanym dziele. Oznaczało ono bowiem miejsce, w którym zbierali się senatorowie przed wejściem do budynku senatu ${ }^{11}$.

W tym miejscu trzeba jeszcze pamiętać, że Historia Augusta nie jest zwyczajnym zbiorem biografii cesarskich, źródłem takim jak inne. Jego autor występował pod sześcioma imionami, ukrył również czas powstania swojego dzieła ${ }^{12}$. Zawiera ono bardzo dużo dziwnych informacji, które ewidentnie sa nieprawdziwe. Autor połączył całkiem wiarygodne dane $z$ passusami pełnymi fantazji. Szczególnie dotyczyło to biografii władców, o których niewiele było wiadomo. $\mathrm{Z}$ braku źródeł twórca $\mathrm{Hi}^{-}$ storia Augusta stworzył własne, wymyślone przez siebie dokumenty, nieznane $z$ innych źródeł historyków. Żywot Heliogabala nie cieszy się zaufaniem badaczy. Jest on mocno skandalizujący ${ }^{13}$. Najwięcej inwencji autora odnajdujemy w drugiej części biografii Heliogabala (rozdziały 18$35)^{14}$, w której podkreślał wady cesarza dla ukazania kontrastu między

11 Varro, Lingua Latina, 5, 156; Valerius Maximus, Facta et dicta memorabilia, 2, 2, 6; Festus, De Verborum Signficatu, 347; Livius, Ab urbe condita, 41, 27, 7. Patrz: Samuel B. Platner, Thomas Ashby, A Topographical Dictionary of Ancient Rome (Oxford : Oxford University Press, 1929), 471; Johannes Straub, „Senaculum, id est mulierum senatus”, Bonner Historia-Augusta-Colloquium, band 5, 1964 (Veröffentlichungsdatum : 1966), 233234; Maria Elefante, „A proposito del Senaculum mulierum”, Rendiconti della Accademia di archeologia, lettere e belle arti della Societŕ Nazionale di Scienze Lettere ed Arti di Napoli, vol. 8, 1982, 91-107; David Rohrbacher, The Play of Allusion, 116.

$12 \mathrm{~W}$ manuskryptach wymieniono sześciu autorów biografii zawartych w tym zbiorze. Sa to: Aelius Spartianus, Iulius Capitolinus, Vulcacius Gallicanus, Aelius Lampridius, Trebellius Polio i Flavius Vopiscus $z$ Syrakuz. Żaden $z$ nich nie jest wymieniony w innym dziele poza Historia Augusta. Mieli oni pisać za czasów Dioklecjana, Maksymiana Herkulijskiego, Konstancjusza Chlorusa, Galeriusza lub Konstantyna Wielkiego. Patrz: Robert Suski, Jowisz, Jahwe, Jezus. Religie $w$ Historia Augusta, (Warszawa : Sub Lupa, 2015), 1-38, 359-386.

13 Ronald Syme, Emperors and Biography: Studies in the Historia Augusta (Oxford : Oxford University Press, 1971), 118. Szacuje się, że żywot Heliogabala obejmuje jedynie $24 \%$ prawdziwych wiadomości, reszta zaś jest wymysłem jej autora: Anthony R. Birley, "Rewriting second- and third-century history in late antique Rome: the Historia Augusta”, Classica, vol. 19, 2006, 23. Birley szacował też, że Quadrigae Tyrannorum nie zawiera w ogóle prawdziwych wiadomości, żywot Aleksandra Sewera 4\%, Diadumeniana i Gety po $5 \%$, Klaudiusza II 10\%, Tacyta $15 \%$, Probusa i Karusa po $17 \%$, Aeliusa $25 \%$, a Aureliana $27 \%$ (Ibidem). $Z$ dokładnością tych wyliczeń można pewnie polemizować, ale w przeważającej części biografii zawartych w Historia Augusta znajduje się bardzo dużo fałszywych wiadomości.

${ }_{14}$ Część badaczy uważa, że pisząc pierwsze rozdziały, autor Historia Augusta posługiwał się niezachowanym zbiorem biografii cesarskich napisanym przez Mariusa Maximusa, a następnie głównym źródłem była jego własna fantazja. Patrz: Tymothy D. Barnes, The Sources of the Historia Augusta, (Bruxelles : Latomus, 1978), 28. 
„złym” Heliogabalem a jego „dobrym” następca, Aleksandrem Sewerem ${ }^{15}$. Część badaczy postrzega żywot władcy zawarty w Historia Augusta jako prześmiewcze nawiązanie do Konstantyna Wielkiego ${ }^{16}$. Oczywiste jest więc, że do tych informacji należy podchodzić $z$ wielką ostrożnością i nie można przyjmować ich bezkrytycznie. Dlatego też najprawdopodobniej wspomniany w tym dziele senat kobiet jest czystą inwencja autora ${ }^{17}$.

Tym bardziej że dla czasów Heliogabala mamy inne źródła (przede wszystkim Herodiana), które nie wspominaja o wprowadzeniu instytucji senatu kobiet ${ }^{18}$. Oczywiście matki Heliogabala i Aleksandra Sewera miały spore aspiracje polityczne. Kasjusz Dion wspominał o obecności Julii Soemias (matki Heliogabala) i jej siostry Julii Mammei (matki Aleksandra Sewera) w senacie obok Aleksandra Sewera podczas adopcji tego ostatniego przez Heliogabala ${ }^{19}$. Informacja ta jest zreszta sprzeczna ze świadectwem pochodzacym z Historia Augusta, gdyż pokazuje, że wcześniej matka Heliogabala w senacie nie bywała. W każdym razie utworzenie senatu dla kobiet przez nielubianego cesarza powinno zostać odnotowane w innych źródłach, a tak się nie stało.

W tej sytuacji pozostaje pytanie o powód, dla którego autor Historia Augusta wymyślił stworzenie zgromadzenia matron przez Heliogabala i Aureliana. Tym bardziej że jego twórcą miał być najbardziej zniewieściały cesarz, a jego odnowicielem najsurowszy ${ }^{20}$. Pierwszy $z$ tych władców jest bardzo negatywnie oceniany w omawianym dziele, a drugi wręcz przeciwnie - podnoszony jest jako wzór ${ }^{21}$. W odnowionym przez Aureliana senacie kobiet czołowa rolę miały odgrywać kapłanki. Co prawda nie wiemy, które, ale można się domyślać, że mogły do nich należeć członki-

15 André Chastagnol, Histoire Auguste. Les empereurs romains des IIe et IIIe siècles, (Paris : R. Laffont, 1994), 499.

16 Lellia Cracco Ruggini, „Elagabalo, Constantino e i culti "Siriaci» nella Historia Augusta”, w: Giorgio Bonamente, François Paschoud (ed.), Historiae Augustae Colloquium Parisinum I, (Bari : Edipuglia, 1991), 123-146; Robert Turcan, „Heliogabale precurseur de Constantin?", Bulletin de l'Association Guillaume Budé, no. 47, 1988, 38-52; André Chastagnol, Histoire Auguste, 139.

17 David Rohrbacher, The Play of Allusion, 116; Richard J.A. Talbert, The Senate of Imperial Rome, (Princeton : Princeton University Press, 1984), 162.

18 Samuel Christian Zinsli, Kommentar zur Vita Heliogabali der Historia Augusta, (Bonn : Habelt Verlag, 2014), 370.

19 Cassius Dion, Historia romana, vol. 79(80), 17, 2.

20 François Paschoud, Histoire Auguste, 5.1: Vies d'Aurélien, Tacite, (Paris : Les Belles Lettres, 1996), 221.

21 Ibidem. 
nie najważniejszych kolegiów, takich jak westalki, kapłanki Bona Dea, Ceres i Hekate ${ }^{22}$.

Oba te passusy od wielu lat przykuwały uwage badaczy. Już Alfred von Domaszewski i Ludwig Friedländer odmawiali im historyczności ${ }^{23}$. Przełomem w ich interpretacji był artykuł Johannesa Strauba z 1966 r., w którym zwrócił on uwage na jakoby ich antychrześcijański wydźwię ${ }^{24}$. Dopatrzył się w tym ironii i nawiązania do kobiet, które zgromadził wokół siebie Hieronim. W epitafium dla Pauli Hieronim nie tylko nazywa ją potomkinią Scypionów i Grakchów, matką Eustochium, lecz także pierwszą $z$ rzymskiego senatu ${ }^{25}$. Tymczasem w ustępie żywota Aureliana najistotniejszą rolę miały odgrywać kapłanki. Według Strauba autor Historia Augusta czynił aluzję do Hieronima, a przez nia polemizował ze zgromadzeniami chrześcijanek ${ }^{26}$. Przeciwstawiał on pobożne Rzymianki $z$ kręgu Hieronima wymyślonym pogańskim matronom ${ }^{27}$.

Hipoteza Strauba szybko znalazła uznanie wśród badaczy zajmujących się Historia Augusta ${ }^{28}$. Zwrócono uwagę na kilka kolejnych tekstów Hieronima, w których szukano natchnienia dla autora tego dzieła, gdy wymyślił senatus mulierum. W liście do córki Pauli, Eustochium, o strzeżeniu dziewictwa, Hieronim apelował, aby nie przebywała w towarzystwie matron, by nie chodziła do domów ludzi szlachetnie urodzonych. Nie chciał, żeby Eustochium często widywała to, czym wzgardziła, postanawiając zostać dziewica. W końcu jako oblubienica Boża nie powinna spieszyć do mężatek. Hieronim zwraca jej uwagę, że winna się uczyć w świętej wyniosłości, iż jest od tamtych lepsza ${ }^{29}$. W liście do Marceli Hieronim przeciwstawiał zgiełk Rzymu trwaniu przy Bogu, które jest

${ }^{22}$ François Paschoud, Histoire Auguste, 5.1, 222.

23 Johannes Straub, Senaculum, 236.

${ }^{24}$ Ibidem, 221-240.

25 Hieronim, Epistulae, 108, 33: „Sequitur titulus sepulchri. Scipio quam genuit, Pauli fudere parentes, Graccorum soboles, Agamemnonis inclyta proles, Hoc iacet in tumulo: Paulam dixere priores, Eustochii genitrix, Romani prima Senatus: Pauperiem Christi, et Bethlemitica rura secuta est”. Patrz: Johannes Straub, Senaculum, 240.

${ }^{26}$ Johannes Straub, Senaculum, 240.

27 Ibidem.

28 André Chastagnol, Recherches sur l'Histoire Auguste, (Bonn : Habelt Verlag, 1970), 15, 86; Jacques Schwartz, „Arguments philologiques pour dater l'Histoire Auguste”, Historia: Zeitschrift für Alte Geschichte, vol. 15, 1966, 463.

${ }^{29}$ Hieronim, Epistulae, 22, 16: „Nolo habeas consortia matronarum: nolo ad nobilium domos accedas: nolo te frequenter videre, quod contemnens, virgo esse voluisti. Sic sibi solent applaudere mulierculae de iudicibus viris, et in aliqua positis dignitate. Si ad Imperatoris uxorem concurrit ambitio salutantium, cur tu facis iniuriam viro tuo? Ad hominis 
niezbędne do zbawienia. Nie tylko wspominał areny, cyrki i teatry, lecz także chrześcijańskie matrony, które maja swoje zebrania i odwiedziny, choć nadal lepiej jest trwać przy Bogu ${ }^{30}$. Stwierdzenie conventu feminarum pojawia się też w traktacie Przeciw Jowinianowi, w którym Hieronim przytaczał argumenty przeciw małżeństwu ${ }^{31}$. Tak więc przypisując tworzenie zgromadzeń kobiet, autor Historia Augusta miałby się naśmiewać z Hieronima. Tak jak Hieronim zgromadził wokół siebie arystokratki, tak Heliogabal ustanowił zgromadzenie matron. W rezultacie czytelnik omawianego dzieła mógłby skojarzyć obie postacie, a to stawiałoby Hieronima w negatywnym świetle.

Większość badaczy postrzega passusy dotyczące senaculum mulierum jako prześmiewczą aluzję do tekstów Hieronima. W tym miejscu należy jednak postawić kilka pytań. Po pierwsze, trzeba naprawdę bardzo dobrze znać dzieła Hieronima, aby dopatrzeć się w interesujących nas fragmentach podobieństw między jego pisarstwem a Historia Augusta. Sprowadzają się one do podobnych stwierdzeń. Nie należy jednak przyjmować, że Rzymianie w końcu IV w. czy na początku V w. tak dobrze i na wyrywki znali twórczość mnicha ze Strydonu. Po drugie, trudno też oczekiwać, aby autor Historia Augusta liczył, że jego czytelnicy z łatwościa odnajdą nawiązania między jego narracją a Hieronima. Sam wielokrotnie powoływał się na fałszywych autorów czy nieprawdziwe dokumenty, więc raczej nie miał najlepszego zdania o swoich czytelnikach. Zwróćmy uwagę, że w liście do Marceli Hieronim nie przypisuje jej obecności w matronarum senatus, które to stwierdzenie ma u niego wydźwięk ironiczny ${ }^{32}$.

Także inne hipotezy thumaczace interesujący nas passus nie sa przekonujące. Tak np. postrzegano ustęp pochodzacy z żywota Heliogabala jako podkreślenie jego antysenatorskiej polityki ${ }^{33}$. Albo też widziano $\mathrm{w}$ tym aluzję do ustanowienia drugiego senatu w Konstantynopolu przez

coniugem, Dei sponsa quid properas? Disce in hac parte superbiam sanctam: scito te illis esse meliorem".

30 Ibidem, 43, 3: „Habeat sibi Roma suos tumultus, arena saeviat, circus insaniat, theatra luxurient, et quia de nostris dicendum est, matronarum quotidie visitetur senatus. Nobis adhaerere Domino bonum est, et ponere in Domino Deo spem nostram 4: ut cum paupertatem istam coelorum regna mutaverint, crumpamus in vocem: Quid enim mihi est in coelo, et a te quid volui super terram? Quo scilicet cum tanta reperiamus in coelo, parva et caduca quaesisse nos doleamus in terra".

31 Hieronim, Adversus Jovinianum, 1, 47.

32 Robert Turcan, Histoire Auguste, 3.1, 166.

33 Samuel Christian Zinsli, Kommentar zur Vita Heliogabali, 371. 
Konstantyna Wielkiego ${ }^{34}$. François Paschoud dostrzegł w senaculum żartobliwe nawiazanie do nowotestamentalnego cenaculum (Mk 15,14; Łk 22,12$)^{35}$. O ile to tłumaczyło passus zawarty w biografii Heliogabala, który ma ewidentnie charakter prześmiewczy, o tyle nie dotyczyło żywota Aureliana, gdzie czyn cesarza nie jest oceniany negatywnie, a raczej przywraca ład i porzacek.

Można więc zadać pytanie, czy owe dwie wzmianki mogły służyć czemuś innemu. Być może anegdotę zawartą w tym dziele nie trzeba czytać przez pryzmat antychrześcijańskiego dyskursu. Uważam, że dużo sensowniejsze jest ich postrzeganie przez pryzmat uprzedzeń wobec kobiet $\mathrm{i}$ ich miejsca w społeczeństwie. Bardzo dobrze to widać w przypadku wzmianki zawartej w żywocie Aureliana. W tym miejscu przypomnijmy, że dla autora Historia Augusta jego panowanie (a także jego krótko rządzacego poprzednika Klaudiusza II) to czas wyjścia cesarstwa $z$ kryzysu, w którym znajdowało się w czasach Waleriana i Galiena. W tym dziele złe czasy, kiedy rządził Galien, przeciwstawia się dobrym, gdy władza znajdowała się w rękach Klaudiusza II czy Aureliana. Jedna z cech charakteryzujących okresy upadku, którym wedle Historia Augusta było panowanie Galiena, był silny wpływ kobiet na rzady. Sam Galien przedstawiony jest jako postać zniewieściała, $z$ wieloma cechami tradycyjnie przypisywanymi kobietom ${ }^{36}$. To wtedy kobiety, widząc słabość cesarza, jego nikczemność, poważyły się wziąć sprawy państwa w swoje ręce tak uczyniły Zenobia ${ }^{37}$ i Wiktoria ${ }^{38}$. Dojście kobiet do władzy w czasach

34 André Chastagnol, Histoire Auguste, 89; Samuel Christian Zinsli, Kommentar zur Vita Heliogabali, 371.

35 François Paschoud, Histoire Auguste, 5.1, 222; Idem, „L'auteur de l'Histoire Auguste est-il un apostat?”, w: François Chausson, Étienne Wolff (ed.), Consuetudinis amor. Fragments d'histoire romaine [IIe-VIe siècles] offerts à Jean-Pierre Callu, (Roma : L'Erma di Bretschneider, 2007), 367-368.

36 Agata Kluczek, „Gallien w Historia Augusta, czyli sordidissimus feminarum omnium”, w: Monika Anna Kubiaczyk, Filip Kubiaczyk (red.), Płeć i władza w kontekstach historycznych $i$ współczesnych, (Gniezno : Instytut Kultury Europejskiej UAM, 2014), 62-63.

37 Historia Augusta, Tyranni triginta, 30, 1-2: „Omnis iam consumptus est pudor, si quidem fatigata re $\mathrm{p}$. eo usque perventum est, ut Gallieno nequissime agente optime etiam mulieres imperarent, et quidem peregrina $<$ e $>$. < peregrina $>$ enim, nomine Zenobia, de qua multa iam dicta sunt, quae se de Cleopatrarum Ptolem<a>eorumque gente iactaret, post Odenatum maritum imperiali sagulo perfuso per umeros, habitu $<\mathrm{Di}>$ donis ornata, diademate etiam accepto, nomine filiorum Herenniani et Timolai diutius, quam femineus sexus patiebatur, imperavit”. Patrz: François Paschoud, Histoire Auguste, 4.3: Vies des Trente Tyrans et de Claude, (Paris : Les Belles Lettres, 2011), 181-185.

38 Historia Augusta, Tyranni triginta, 31, 1: „Non tam digna res erat, ut etiam Vitruvia sive Victoria in litteras mitteretur, nisi Gallieni mores hoc facerent, ut memoria dign<a>e 
Galiena dla autora Historia Augusta miało być oznaką upadku państwa. Co więcej, wpływ na rządy w tym czasie miały cudzoziemki, jak np. Zenobia ${ }^{39}$ czy nałożnica Galiena, Pippa, córka króla barbarzyńców ${ }^{40}$. Powodem do chwały Aureliana było nie tylko przywrócenie rządów rzymskich nad Orientem, lecz także wyzwolenie go spod wpływu kobiety, co było dodatkowym upokorzeniem dla jego mieszkańców ${ }^{41}$. W takim świetle podkreślanie w tym dziele wielkoduszności Aureliana wobec Zenobii, który, gdy ja pokonał, nie uśmiercił jej, ale wysłał do Italii i tam pozwolił jej wyjść za mąż, nabierały nowego znaczenia. Cesarz zachował ja przy życiu i pozwolił żyć jak przystało szanowanej rzymskiej matronie ${ }^{42}$. Państwo rzymskie powróciło zaś do naturalnego, wedle jej autora, stanu, w którym rządza mężczyźni, a kobiety zajmują się domem. Podobnie można rozumieć przywrócenie zgromadzenia matron, co według Historia Augusta miał uczynić Aurelian. Tym fikcyjnym czynem cesarz zakończył czas, gdy kobiety wcielały się w męskie role, takie jak sprawowanie rządów, i wróciły do swoich „naturalnych” kobiecych zajęć.

Do podobnych wniosków możemy dojść, analizując passus pochodzacy $z$ żywota Heliogabala. Cesarz ten zaliczany jest przez autora zbioru biografii cesarskich do najgorszych rzymskich władców, obok Kaliguli, Nerona czy Witeliusza ${ }^{43}$. Nie zasłużył on na miłość ludu, senatu

etiam mulieres censerentur”. O Wiktorii patrz: Tadeusz Kotula, „Wiktoria - matka cesarza: rzeczywistość a legenda", Eos, t. 78, 1990, 361-369.

39 Historia Augusta, Tyranni triginta, 30, 2.

40 Historia Augusta, Gallieni duo, 21,3.

41 Historia Augusta, Divus Aurelianus, 41, 7-10: „Respirare certe post infelicitatem Valeriani, post Gallieni mala imperante Claudio coeperat nostra res $\mathrm{p}$.; $\mathrm{a}<\mathrm{t}>$ eadem reddita fuerat Aureliano toto penitus orbe vincente. ille nobis Gallias dedit, ille Italiam liberavit, $\mathrm{i}<11>\mathrm{e}$ Vindelicis iugum barbaricae servitutis amovit. illo vincente Illyricum restitutum est, redditae Romanis legibus Thraciae. ille, pro pudor[e], orientem femineo pressum iugo in nostra iura restituit, ille Persas, insultantes adhuc Valeriani nece, fudit, fugavit, oppressit. illum Saraceni, Blemmyes, Exomit <a>e, B[r]actrani, Seres, Hiberi, Albani, Armenii, populi etiam Indorum veluti praesentem <pa>ene venerati sunt deum".

42 Historia Augusta, Tyranni triginta, 30, 27: „Huic < vita> ab Aureliano concessa est, ferturque vixisse cum liberis matronae iam more Romanae data sibi possessione in Tiburti, quae hodieque Zenobia dicitur, non longe ab Hadriani palatio atque ab eo loco, cui nomen est Concae".

43 Historia Augusta, Hel. 1, 1-2: „Vitam Heliogabali Antonini, qui Varius etiam dictus est, numquam in litteras misissem, ne quis fuisse Romanorum principem sciret, nisi ante Caligulas et Nerones et Vitellios hoc idem habuisset imperium. Sed cum eadem terra et venera ferat et frumentum atque alia salutaria, eadem serpentes et cicures, conpensationem sibi lector diligens faciet, cum legerit Augustum, Traianum, Vespasianum, Hadrianum, Pium, Titum, Marcum contra hos prodigiosos tyrannos". 
i żołnierzy ${ }^{44}$. Wśród wielu krytykowanych cech (takich jak bezczeszczenie tradycyjnej rzymskiej religii ${ }^{45}$, zabijanie młodych chłopców na ofiarę ${ }^{46}$, wyznaczanie na najwyższe urzędy ludzi niegodnych ${ }^{47}$, gardzenie senatem $^{48}$ ) znalazło się też życie erotyczne imperatora, któremu poświęcono sporo miejsca, często wracając do tego tematu. Autor Historia Augusta ustawicznie zwraca uwage na homoseksualizm władcy, krytykuje go za życie w rozpuście i utrzymywanie stosunków $z$ mężczyznami ${ }^{49}$. Władca miał wyszukiwać mężczyzn o wielkich penisach, aby korzystać z ich usług $^{50}$, miał też grać role żeńskie. Biograf $z$ niesmakiem i zażenowaniem pisał o wcielaniu się władcy $\mathrm{w}$ rolę Wenus podczas przedstawienia ${ }^{51}$. Cesarz miał także traktować niejakiego Zotikosa jak męża ${ }^{52}$. Z naszego punktu widzenia nie jest istotne, ile prawdy jest w tych opisach. Tak jak w przypadku Galiena, autor Historia Augusta przedstawiał Heliogabala jako osobę zniewieściałą, która nie pełniła standardowych ról męskich (a zarazem jest nie-Rzymianinem $)^{53}$.

44 Historia Augusta, Antoninus Heliogabalus, 17, 7.

45 Ibidem, 6-7.

46 Ibidem, 8, 1.

47 Ibidem, 11, 1.

48 Ibidem, 20, 1.

49 Ibidem, 5, 1: „Ergo cum hibernasset Nicomediae atque omnia sordide ageret inireturque a viris et subaret”.

50 Historia Augusta, Antoninus Heliogabalus, 5, 3: „Romae denique nihil egit aliud, nisi ut emissarios haberet, qui ei bene vasatos perquirerent eosque ad aulam perducerent, ut eorum conditionibus frui posset".

51 Ibidem, 4-5: „Agebat praeterea domi fabulam Paridis ipse Veneris personam subiens, ita ut subito vestes ad pedes defluerent, nudusque una manu ad mammam altera pudendis adhibita ingenicularet posterioribus eminentibus in subactorem reiectis et oppositis. Vultum praeterea eodem quo Venus pingitur, schemate figurabat corpore toto expolitus eum fructum vitae praecipuum existimans, si dignus atque aptus libidini plurimorum videretur".

52 Historia Augusta, Antoninus Heliogabalus, 10, 2-5: „Zoticus sub eo tantum valuit, ut ab omnibus officiorum principibus sic haberetur quasi domini maritus. Erat praeterea idem Zoticus, qui hoc familiaritatis genere abutens omnia Heliogabali dicta et facta venderet fumis quam maxime divitias enormes parans, cum aliis minaretur, aliis polliceretur, omnes falleret egrediensque ab illo singulos a[u]diret dicens: "De te hoc locutus sum, de te hoc audivi, de te hoc futurum est". Ut sunt homines huius modi, qui si admissi fuerint ad nimiam famimiaritatem principum, famam non solum malorum sed et bonorum principum vendunt et qui stultitia vel innocentia imperatorum, qui hoc non perspiciunt, infami rumigeratione pascuntur. Nubsit et co<it cum illo $>$ ita, ut et pronubam haberet clamaretque "Concide Magire", et eo quidem tempore quo Zoticus aegrotabat". O Zotikosie - patrz: Samuel Christian Zinsli, Kommentar zur Vita Heliogabali, 465-467.

53 Samuel Christian Zinsli, „Vari-ations in the Historia Augusta”, w: Leonardo de Arrizabalaga y Prado (ed.), Varian Studies Volume Three: A Varian Symposium, (Cambridge : Cambridge Scholars Publishing, 2017), 77-78. 
Za Heliogabala to kobiety miały wchodzić w role męskie. Dotyczyło to matki cesarza Julii Soemias i babki Julii Maesy (nazywanej przez autora Historia Augusta Varia $)^{54}$. Wobec obu poświadczony jest epigraficznie tytuł mater castrorum et senatus ${ }^{55}$. Oczywiście nie oznaczał on możliwości brania udziału w posiedzeniach senatu ${ }^{56}$. W końcu nosiła go wcześniej Julia Domna, żona Septymiusza Sewera, a zarazem siostra Julii Maesy ${ }^{57}$. W Historia Augusta twierdzi się, że babka cesarza nie tylko jako pierwsza $z$ kobiet weszła do senatu, lecz także brała udział w redagowaniu jego uchwał i wypowiadała swoje $z$ danie ${ }^{58}$. Ponadto zmusiła Heliogabala do wystapienia razem $z$ Aleksandrem Sewerem, aby pokazać jedność między kuzynami. Towarzyszyła wnukowi w senacie ${ }^{59}$. W żywocie Heliogabala odnajdujemy więc podobny schemat, co w biografii Galiena. Cesarz zły, gdyż zniewieściały, prowadzi do wchodzenia kobiet w męskie role. Dotyczyło to zarówno babki cesarza, jak i jego matki Julii Soemias. Ta przedstawiona została jako bardzo zła osoba, $z$ wieloma stereotypowymi przywarami, jakie przydawano złym cesarzowym. Dla autora Historia Augusta była ona godna swojego syna i okryta największa hańbą ${ }^{60}$. To ona faktycznie sprawowała władzę w państwie, gdyż cesarz

54 O Julii Maesie w Historia Augusta - patrz: Samuel Christian Zinsli, Kommentar zur Vita Heliogabali, 463-465.

55 ILS 470, 476; AE 1956, 144. Patrz: Martijn Icks, The crimes of Elagabalus, 19.

56 Richard J.A. Talbert, The Senate of Imperial Rome, 162.

57 Patrz: Herbert W. Benario, Julia Domna, „Mater Senatus et Patriae”, Phoenix, vol. 12, 1958, 67-70; Wolfgang Kuhoff, „Iulia Aug. mater Aug. n. et castrorum et senatus et patriae", Zeitschrift für Papyrologie und Epigraphik, vol. 97, 1993, 259-271; Barbara Levick, Julia Domna. Syrian Empress, (London-New York : Routledge, 2007), 93; Danuta Okon, „Iulia Augusta mater w świetle źródeł epigraficznych”, Przeglad Zachodniopomorski, nr 2, 2012, 7-16.

58 Historia Augusta, Antoninus Heliogabalus, 12, 3: „Cum ingressus est vel castra vel curiam aviam suam Variam nomine, de qua superius dictum est, secum induxit, ut eius auctoritate honestior fieret, quia per se non poterat; nec ante eum, quod iam diximus, senatum mulier ingressa est ita, ut ad scribendum rogaretur et sententiam diceret". Doszukiwano się tutaj aluzji do wydarzeń albo z IV w. (Konstantyn Wielki) lub początku V w. (Honoriusz, Eutropiusz). Jest to jednak zbyt ulotne, aby traktować to na serio. Patrz: Samuel Christian Zinsli, Kommentarzur Vita Heliogabali, 499-500.

59 Historia Augusta, Antoninus Heliogabalus, 15, 6: „Ad extremum cum ei avia et mater dicerent inminere milites ad eius exitium, nisi concordiam viderent inter se consobrinorum, sumpta praetexta hora diei sexta processit ad senatum avia sua ad senatum vocata et ad sellam perducta”. Patrz: Samuel Christian Zinsli, Kommentar zur Vita Heliogabali, 638-540.

60 Historia Augusta, Antoninus Heliogabalus, 18, 2: „Occisa est cum eo et mater Symiamira, probrosissima mulier et digna filio". 
nie uczynił nic bez jej woli ${ }^{61}$. Tak więc $z$ jednej strony miała uczestniczyć w życiu politycznym, które było zastrzeżone dla mężczyzn. $Z$ drugiej zaś prowadziła się równie źle, jak jej syn. Żyła na sposób nierządnicy, mając liczne romanse ${ }^{62}$. Autor Historia Augusta twierdził, że Heliogabal kazał senatorowi zaprosić jego matkę na pierwsze posiedzenie, po czym zasiadała w miejscu konsularów, była świadkiem podejmowania przez senat uchwał. Weszła do senatu jak mężczyzna. Heliogabal był zaś jedynym cesarzem, za którego coś takiego się stało ${ }^{63}$. Wreszcie po jego upadku nie tylko zabito jego matkę, lecz także zabroniono wchodzenia kobietom do senatu, a ten, przez którego to by się stało, miał być poświęcony bogom podziemnym ${ }^{64}$. Przy czym żadne inne źródło nie sugeruje, aby takie rozporządzenie zostało wydane. Autor Historia Augusta wyolbrzymia rolę kobiet za panowania Heliogabala i Aleksandra Sewera. Wszystko więc na to wskazuje, że ów zakaz też był fikcyjny ${ }^{65}$. W omawianym dziele $z$ jednej strony pokazywano przejmowanie przez kobiety męskich ról, z drugiej zaś przedstawiano je prześmiewczo. Gdy miał powstać dla nich drugi senat, one nadal zajmowały się sposobem witania czy biżuterią ${ }^{66}$. Niepoważny cesarz stworzył niepoważną instytucję.

${ }_{61}$ Ibidem, 2, 1: „Hic tantum Symiamirae matri deditus fuit, ut sine illius voluntate nihil in re p. faceret". O tym passusie - patrz: Samuel Christian Zinsli, Kommentar zur Vita Heliogabali, 340.

${ }^{62}$ Historia Augusta, Antoninus Heliogabalus, 2, 1-2: „cum ipsa meretricio more vivens in aula omnia turpia exerceret, Antonino autem Caracallo stupro cognita, ita ut hic vel Varius vel Heliogabalus vulgo conceptus putaretur; et aiunt quidam Varii etiam nomen idcirco eidem inditum a condiscipulis, quod vario semine, de meretrice utpote, conceptus videretur". W tym miejscu zwróćmy uwagę, że ani Kasjusz Dion, ani Herodian nie komentowali prowadzenia się Julii Soemias (Samuel Christian Zinsli, Kommentar zur Vita Heliogabali, 342).

63 Historia Augusta, Antoninus Heliogabalus, 4,1-2: „Deinde ubi primum diem senatus habuit, matrem suam in senatum rogari iussit. quae cum venisset, vocata ad consul $<\mathrm{u}>\mathrm{m}$ subsellia[m] [a]scribendo adfuit, id est senatus consulti conficiendi testis, solusque omnium imperatorum fuit, sub quo mulier quasi clarissima loco viri senatum ingressa est”. Patrz: Samuel Christian Zinsli, Kommentar zur Vita Heliogabali, 368-369.

${ }^{64}$ Historia Augusta, Antoninus Heliogabalus, 18, 3: „Cautumque ante omnia post Antoninum Heliogabalum, ne umquam mulier senatum ingrederetur utique inferis eius caput dicaretur devovereturque, per quem id esset factum”. Część badaczy dostrzegała w tym passusie aluzję do skazania na śmierć wdowy po Stylichonie przez senat oraz Galię Placidię (Zosimos, Historia Nova, 5, 38, 1). Patrz: Samuel Christian Zinsli, Kommentar zur Vita Heliogabali, 582.

65 Samuel Christian Zinsli, Kommentar zur Vita Heliogabali, 581.

66 André Chastagnol, „Les femmes dans l'ordre sénatorial: titulature et rang social à Rome”, Revue Historique, fasc. 1(531), 1979, 24. 


\section{Zakończenie}

W obu wypadkach autor Historia Augusta wymieniał senat kobiet w momencie ich powrotu do tradycyjnych ról społecznych. Senat kobiet pełni trochę inną funkcję $\mathrm{w}$ tych opowieściach. W żywocie Heliogabala stworzył go zniewieściały cesarz, za którego kobiety (matka i babka) wchodziły w męskie role. Zgromadzenie to jest wspominane jednak $z$ powodu nieudolności kobiet, które nie potrafią wejść w męską rolę, co w rezultacie prowadzi do parodii prawdziwego senatu. Takie ukazanie senatu kobiet pełni więc tutaj rolę potwierdzenia niemożności odnalezienia się niewiast w męskim świecie. W żywocie Aureliana powrót do tego zagadnienia odgrywa inną rolę. Męski cesarz, który przywraca cesarstwu należna pozycję, odtwarza instytucje dla kobiet, aby wrócić do tradycyjnych męskich i żeńskich ról. W obu wypadkach mamy jednak do czynienia $z$ wyśmiewaniem się $z$ chęci odgrywania przez kobiety ról, które społecznie zastrzeżone były dla mężczyzn.

\section{Bibliografia}

\section{Źródła:}

$\mathrm{AE}$ - L'Année épigraphique, Paris 1888.

Cassius, Dion. Historia romana, ed. Ursul Philip Boissevain, Cassii Dionis

Cocceiani Historiarum romanarum quae supersunt, Berlin 1885-1901. CIL - Corpus Inscriptionum Latinarum, Berlin 1863.

Desau - Hermann Dessau, Inscriptiones Latinae Selectae, Berlin 1982-1916.

Festus, De verborum significatu, ed. Wallace Martin Lindsay, Sexti Pompei

Festi De verborum significatu quae supersunt cum Pauli epitome, Leipzig 1913.

Hieronim, Adversus Jovinianum, ed. Luce Robinet, Jerome Adversus Jovinianum, Paris 2004.

Hieronim, Epistulae, ed. Jérôme Labourt, Jerome, Correspondance, Paris 1949-1954.

Historia Augusta, ed. Ernst Hohl, Scriptores Historiae Augustae, Leipzig 1965.

Livius, Ab Urbe Condita, ed. Robert Seymour Conway, Carl Flamstead Walters, T. Livi: ab urbe condita, Oxford 1914-1935. 
Suetonius, De vita Caesarum, ed. Maximilian Ihm, C. Suetonii Tranquilli opera. Vol. 1. De vita Caesarum libri VIII, Leipzig 1908.

Valerius Maximus, Facta et dicta memorabilia, ed. John Briscoe, Valeri Maximi facta et dicta memorabilia, Stuttgart 1998.

Zosimos, Historia nova, ed. François Paschoud, Histoire Nouvelle, Paris 1971-1989.

\section{Opracowania:}

Arrizabalaga y Prado, Leonardo. Varian Studies Volume One: Varius, (Cambridge : Cambridge Scholars Publishing, 2017). ISBN 978-1-4438-9864-5.

Barnes, Timothy D. The Sources of the Historia Augusta, (Bruxelles : Latomus, 1978). ISBN 2870310056.

Benario, Herbert W. „Julia Domna: Mater Senatus et Patriae”, Phoenix, vol. 12, 1958, 67-70.

Birley, Anthony. „Rewriting second- and third-century history in late antique Rome: the Historia Augusta”, Classica, vol. 19, 2006, 19-29.

Chastagnol, André. Histoire Auguste. Les empereurs romains des IIe et IIIe siècles, (Paris : R. Laffont, 1994). ISBN 9782221057346.

Chastagnol, André. „Les femmes dans l'ordre sénatorial: titulature et rang social à Rome", Revue Historique, fasc. 1(531), 1979, 3-28.

Chastagnol, André. Recherches sur l'Histoire Auguste, (Bonn : Habelt Verlag, 1970). ISBN 3774904200.

Cracco Ruggini, Lellia. „Elagabalo, Constantino e i culti "Siriaci” nella Historia Augusta", w: Giorgio Bonamente, François Paschoud (ed.), Historiae Augustae Colloquium Parisinum I, (Bari : Edipuglia, 1991).

Donati, Angela. „Sull'iscrizione lanuvina della curia mulierum”, Rivista di storia antica, vol. 1, 1971, 235-237.

Elefante, Maria. „A proposito del Senaculum mulierum”, Rendiconti della Accademia di archeologia, lettere e belle arti della Societŕ Nazionale di Scienze Lettere ed Arti di Napoli, vol. 8, 1982, 91-107.

Hemelrijk, Emily. Hidden Lives, Public Personae: Women and Civic Life in the Roman West, (Oxford : Oxford University Press, 2015). ISBN 9780190251888. 
Hemelrijk, Emily. Matrona docta, Educated women in the Roman élite from Cornelia to Julia Domna, (London-New York : Routledge, 1999). ISBN 978-0415341271.

Icks, Martijn. The crimes of Elagabalus: the life and legacy of Rome's decadent boy emperor, (London : I.B. Tauris, 2011). ISBN 9781848853621.

Kluczek, Agata. „Gallien w Historia Augusta, czyli sordidissimus feminarum omnium", w: Monika Anna Kubiaczyk, Filip Kubiaczyk (red.), Płeć i władza w kontekstach historycznych i wspókczesnych, (Gniezno : Instytut Kultury Europejskiej UAM, 2014), 53-70. ISBN 978-83-60251-89-8.

Kotula, Tadeusz. „Wiktoria - matka cesarza: rzeczywistość a legenda”, Eos, t. 78, 1990, 361-369. ISSN 0012-7825.

Kuhoff, Wolfgang. „Iulia Aug. mater Aug. n. et castrorum et senatus et patriae", Zeitschrift für Papyrologie und Epigraphik, vol. 97, 1993, 259-271. ISSN 0084-5388.

Okoń, Danuta. „Iulia Augusta mater w świetle źródeł epigraficznych”, Przeglad Zachodniopomorski, nr 2, 2012, 7-16. ISSN 0552-4245.

Paschoud, François. Histoire Auguste, 4.3: Vies des Trente Tyrans et de Claude, (Paris : Les Belles Lettres, 2011). ISBN 978-2-251-01460-9.

Paschoud, François. Histoire Auguste, 5.1: Vies d'Aurélien, Tacite, (Paris : Les Belles Lettres, 1996). ISBN 9782251013954.

Paschoud, François. „L'auteur de 1'Histoire Auguste est-il un apostat?”, w: François Chausson, Étienne Wolff (ed.), Consuetudinis amor. Fragments d'histoire romaine [IIe-VIe siècles] offerts à Jean-Pierre Callu, (Roma : L’Erma di Bretschneider, 2007), 357-370. ISBN 978-88-82652-16-6.

Pasqualini, Anna. „CIL XIV 2120, la curia mulierum di Lanuvio e l'«associazionismo" delle donne romane", w: Alfredo Buonopane, Francesca Cenerini (ed.), Donna e vita cittadina nella documentazione epigrafica, (Faenza : Stabilimento Grafico Lega, 2005), 259-274. ISBN 978-88-75940-90-4. Platner, Samuel Ball, Ashby, Thomas. A Topographical Dictionary of Ancient Rome, (Oxford : Oxford University Press, 1929).

Pomeroy, Sarah B. Goddesses, Whores, Wives and Slaves: Women in Classical Antiquity, (New York : Schocken Books, 1975). ISBN 0-8052-3562-0. Rohrbacher, David. The Play of Allusion in the Historia Augusta, (Madison : University of Wisconsin Press, 2016). ISBN 9780299306007. 
Schwartz, Jacques. „Arguments philologiques pour dater l'Histoire Auguste”, Historia: Zeitschrift für Alte Geschichte, vol. 15, 1966, 454-465. ISSN 0018-2311.

Straub, Johannes. „Senaculum, id est mulierum senatus”, Bonner Historia-Augusta-Colloquium, band 5, 1964, (Veröffentlichungsdatum : 1966), 221-240.

Suski, Robert. Jowisz, Jahwe, Jezus. Religie w Historia Augusta, (Warszawa : Sub Lupa, 2015). ISBN 978-83-64003-15-8.

Syme, Ronald. Emperors and Biography: Studies in the Historia Augusta, (Oxford : Oxford University Press, 1971). ISBN 0198143575.

Talbert, Richard J.A. The Senate of Imperial Rome, (Princeton : Princeton University Press, 1984). ISBN 9780691102382.

Turcan, Robert. Histoire Auguste, 3.1: Vies de Macrin, Diaduménien, Héliogabale, (Paris : Les Belles Lettres, 1993). ISBN 9782251013695.

Turcan, Robert. „Heliogabale precurseur de Constantin?”, Bulletin de l'Association Guillaume Budé, no. 47, 1988, 38-52. ISSN 0004-5527.

Zinsli, Samuel Christian. „Vari-ations in the Historia Augusta”, w: Leonardo de Arrizabalaga y Prado (ed.), Varian Studies Volume Three: A Varian Symposium, (Cambridge : Cambridge Scholars Publishing, 2017). ISBN 978-1-4438-9576-7.

Zinsli, Samuel Christian. Kommentar zur Vita Heliogabali der Historia Augusta, (Bonn : Habelt Verlag, 2014). ISBN 978-3-7749-3856-4. 